\title{
Mathematical modeling of structural-sensitive nanocomposites deformation *
}

\author{
V.S. Zarubin**, E.S. Sergeeva*** \\ The Bauman Moscow State Technical University, Moscow, Russia \\ «SSC Kompozit» (Joint-Stock Company), Korolev, Russia
}

Results of nanocomposites deformation numerical modeling are shown. Large difference in the values of mechanical characteristics at the interface between the matrix and the inclusion is typically for such kind of materials. This problem was solved with using finite elemental complex ANSYS by means of server processors and video cards TESLA. The analytical method - the dual variational formulation of the elasticity problem - was realized for verification of numerical model. Due to results in this paper we can get estimates of nanocomposites mechanical properties, which are important for model construction from such material.

Keywords: numerical modeling; structural-sensitive materials; interface; deformation; mathematical modeling

Introduction. Composite materials have recently been widely used in various fields of technology, including in structures and devices subject to mechanical influences [1-3]. As a perspective reinforcing inclusions for composites, various nanostructural high-modulus and highstrength elements from graphene, including its particles, single-layer and multilayer carbon nanotubes (SCNT and MCNT), fullerenes, nanoclusters, etc. are of particular interest [4-6]. The obtained quantitative estimates show that even a relatively small volume concentration of such reinforcing inclusions leads to a substantial increase in the elastic properties of the composite [7].

When designing structures from composites, it is necessary to have estimates of the elastic properties of such materials. There are various ways of modeling the elastic properties of composites: analytical, numerical without the use of the finite element method (FEM) and numerical methods using FEM. Each of the research methods has both advantages and disadvantages. For example, analytical methods are thoroughly investigated, but have a number of limitations and assumptions that are not always correct. Numerical methods do not require a large number of simplifications, but this advantage is associated with large computational costs in time and capacities for processing the results.

This paper is devoted to the construction and verification of a finite element model for researching the elastic properties of a nanocomposite consisting of a matrix reinforced with ball

\footnotetext{
* The research was carried out within the framework of the implementation of the basic part of the state task of the Ministry of Education and Science of the Russian Federation (project 9.7784.2017 / BC) and also as a part of grant MK1069.2018.8 of the program of the President of Russian Federation for state support of young candidates of science.

${ }^{* *}$ E-mail: zarubin@bmstu.ru.

*** E-mail: sergeeva.e.s@ outlook.com.
} 
inclusions simulating ball nanoclusters from SWCNTs. Verification of the constructed finite-element model is carried out with the help of analytical models: the self-consistency method and the dual variational formulation of the elasticity problem.

1. Finite element model. Nanoclusters from SCNT are conglomerates of SCNT formed under the action of van der Waals forces. The assumption is made of the chaotic orientation of the SCNT rotation axes in the nanoclusters, which makes it possible to consider such an object isotropic with a bulk modulus of elasticity $\mathrm{K}^{*}$ and the shear modulus $\mathrm{G}^{*}$.

An important characteristic of the composite, in addition to the properties of the matrix material, determined by the bulk modulus of elasticity $\mathrm{K}$ and the shear modulus $\mathrm{G}$, and inclusions, is the reinforcement circuit. In this paper, we chose a reinforcement scheme analogous to a cubic crystal lattice. In this case, the periodic cell of the composite can be chosen in two equivalent ways: a cube with eight parts of the ball in the corners and a cube with a ball in the center. In the course of constructing the finite-element problem, both variants of the periodic cell of the composite are considered. A representative element of the structure of the composite is a cube with the eighth part of the ball inclusion in one of the angles, taken as the origin of a rectangular Cartesian coordinate system.

To model the elastic characteristics of a composite, the tensile along one coordinate axis and the shift of the representative element are realized with the help of kinematic and force boundary conditions (BC). In the case of a cube with eighth parts of the sphere in the corners on the faces of the cube belonging to the coordinate planes, the symmetry conditions are given, and on the other the BC, in the case of the cube with the ball in the center - vice versa. Simulation was carried out in ANSYS software using server processors and TESLA video cards.

When stretching along one axis in the case of kinematic BC the displacement is assumed to be constant and equal to $1 \%$ of the representative size of the representative volume. Hence, from Hooke's law we obtain a relation for finding the value of the bulk modulus of elasticity $C_{11}$ and $C_{12}$ relationship:

$$
K_{1}=\frac{C_{11}+2 C_{12}}{3}
$$

In the case of power $\mathrm{BC}$ the stress are constant. With this type of $\mathrm{BC}$, the ratio for the module $K$ composite is associated with the elements of the matrix of compliance coefficients $S_{11}$ and $S_{12}$ equality:

$$
K_{2}=\frac{1}{3\left(S_{11}+2 S_{12}\right)} .
$$

From the consideration of the shift with the help of geometric and power BC we can express the modulus $G$ composite through an element $C_{44}$ matrix of coefficients of elasticity and $S_{44}$ matrices of compliance coefficients and write:

$$
G_{1}=C_{44}, G_{2}=\frac{1}{S_{44}}
$$


The results of calculating the stress-strain state of a representative element were processed using the mechanical module built into the ANSYS package APDL and a specially developed software module, which makes it possible to obtain estimates of the elastic moduli of a composite with a selected arrangement of inclusions.

The developed software module allows the formation of matrices $\mathrm{C}$ and $\mathrm{S}$ coefficients of elasticity and compliance of the composite from the list of stress and strain values for each element, which are the results of calculation of the software complex ANSYS, as well as their subsequent averaging.

In numerical modeling, the twenty - node three - dimensional finite elements SOLID186 and SOLID 187 were used with a thickening in the contact area of the matrix and the ball inclusion (fig. 1).

The contact of the inclusion and the matrix is modeled in the form of a transition layer, on which 10 elements are chosen along the thickness. The total number of grid elements is selected based on preliminary testing on the model task and is 1.5 million elements.

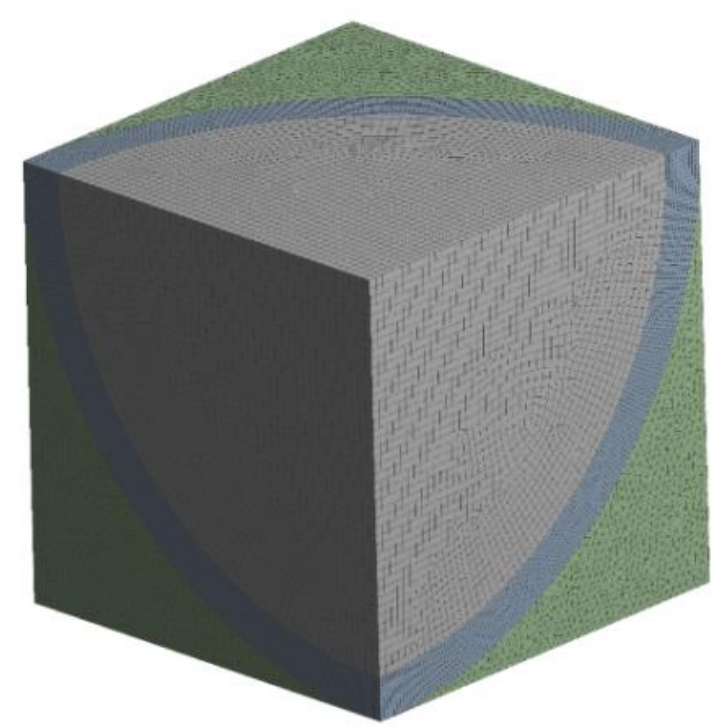

Fig. 1. The constructed grid in a representative volume

2. Evaluation of the efficiency of the numerical model. To evaluate the results obtained with the help of numerical modeling, an analytical method is used the dual variational form of the linear elasticity model applied to an inhomogeneous linearly elastic solid body [8]. This form contains two alternatives functional (minimized and maximized), which on true distributions of displacements and stresses reach equal in value extremes.

Two-sided estimates can be constructed with reference to effective characteristics that link together averaged over a representative volume $V$. Composite tensors of the second rank of stresses and deformation, respectively 


$$
\langle\boldsymbol{\sigma}\rangle=\frac{1}{V} \int_{V} \boldsymbol{\sigma}(M) d V(M), \quad\langle\boldsymbol{\varepsilon}\rangle=\frac{1}{V} \int_{V} \boldsymbol{\varepsilon}(M) d V(M),
$$

where $\sigma(M)$ and $\varepsilon(\mathrm{M})$ are the tensors that determine the stress-strain state in the vicinity of the point $M \in V$.

In the absence of volume forces and the specification of kinematic boundary conditions on the surface $\mathrm{S}$ limiting the volume $\mathrm{V}$ functional that reaches a minimum on the true distribution of displacements in a closed region $\bar{V}=V \cup S$, has the form [9]

$$
J_{1}=\frac{1}{2} \int_{V} \boldsymbol{\varepsilon}(M) \cdots \mathbf{C}^{*}(M) \cdots \boldsymbol{\varepsilon}(M) d V(M), \quad M \in V
$$

where $C^{*}$ is the tensor corresponding to local values of the matrix elasticity coefficients and spherical inclusions in the volume $\mathrm{V}$.

With the functional homogeneous deformed state admissible for this functional, determined by the tensor $\varepsilon_{0}=\langle\varepsilon\rangle$ with components $\varepsilon_{i j}=$ const, we can write the inequality [9]

$$
\frac{1}{2} \int_{V} \mathbf{C}^{*}(M) d V(M) \geq \mathbf{C}_{*}, \quad M \in V
$$

Equivalent to two inequalities containing linear invariants of tensors $\mathrm{C}^{*}$ and $\mathrm{C}$,

$$
\frac{1}{V} \int_{V} \mathbf{C}^{*} \cdots \mathbf{V} d V(M) \geq 9 K_{*}, \frac{1}{V} \int_{V} \mathbf{C}^{*} \cdots \mathbf{D} d V(M) \geq 10 G_{*},
$$

where $V$ and $D$ are the volume and deviator components of the unit tensor of the fourth rank. This allows for the effective values of the elastic modules $K$ and $G$ composite to present the upper bounds $K$ and $G$ as

$$
\tilde{K}_{+}=1-C_{V}+C_{V} \frac{K^{\bullet}}{K^{\circ}}, \quad \tilde{G}_{+}=1-C_{V}+C_{V} \frac{G^{\bullet}}{G^{\circ}}
$$

where $\tilde{K}_{+}=\frac{K_{+}}{K^{\circ}}, \tilde{G}_{+}=\frac{G_{+}}{G^{\circ}}, C_{V}$ is the volume concentration of inclusions.

In the absence of volume forces and given force boundary conditions on a surface bounding the volume $V$ functional maximized on the true stress distribution in the closed region $\bar{V}$, has the form [9]

$$
J_{2}=-\frac{1}{2} \int_{V} \boldsymbol{\sigma}(M) \cdots \mathbf{S}^{*}(M) \cdots \boldsymbol{\sigma}(M) d V(M), \quad M \in V,
$$


where $S^{*}(M)$ is the tensor corresponding to local values of the coefficients of compliance of the matrix and inclusions in the volume $V$. With the homogeneous stress state admissible for this functional, determined by the tensor $\varepsilon_{0}=\langle\varepsilon\rangle$ with components $\varepsilon_{i j}=$ const, we can write [9]

$$
\begin{aligned}
-\frac{1}{2} \int_{V} \boldsymbol{\sigma}_{0} \cdots \mathbf{S}^{*} \cdots \boldsymbol{\sigma}_{0} d V(M) & \leq-\frac{1}{2} \int_{V} \boldsymbol{\sigma}(M) \cdots \mathbf{S}^{*}(M) \cdots \boldsymbol{\sigma}(M) d V(M)= \\
& =-\frac{V}{2} \boldsymbol{\sigma}_{0} \cdots \mathbf{S}^{*} \cdots \boldsymbol{\sigma}_{0} .
\end{aligned}
$$

This implies the inequalities [9]:

$$
\frac{1}{V} \int_{V} \mathrm{~S}^{*} \cdots \mathbf{V} d V(M) \geq 1 / K_{*}, \quad \frac{1}{V} \int_{V} \mathrm{~S}^{*} \cdots \mathbf{D} d V(M) \geq \frac{5}{2 G_{*}},
$$

from which we obtain lower bounds $K$ and $G$ for effective values of modules $K$ and $G$ composite in the form:

$$
\begin{gathered}
\tilde{K}_{-}=\left(1-C_{V}+\frac{K^{\circ}}{K^{\bullet}} C_{V}\right)^{-1}, \quad \tilde{G}_{-}=\left(1-C_{V}+\frac{G^{\circ}}{G^{\bullet}}\right)^{-1}, \\
\tilde{K}_{-}=K_{-} / K^{\circ}, \tilde{G}_{-}=G_{-} / G^{\circ} .
\end{gathered}
$$

3. An example of calculation and analysis of results. A quantitative analysis of the dependence of the elastic characteristics of the composite on the input parameters of the matrix, reinforcing elements, and the composition of the material was made using the example of a composite with an aluminum matrix, $K^{\circ}=76.3 \mathrm{GPa}$ and $G^{\circ}=25.3 \mathrm{GPa}$ [2]. As input information on the elastic properties of globular nanoclusters, the following values are chosen: $K^{\bullet}=385.7 \mathrm{GPa}$ and $G^{\bullet}=196.1 G P a[10]$.

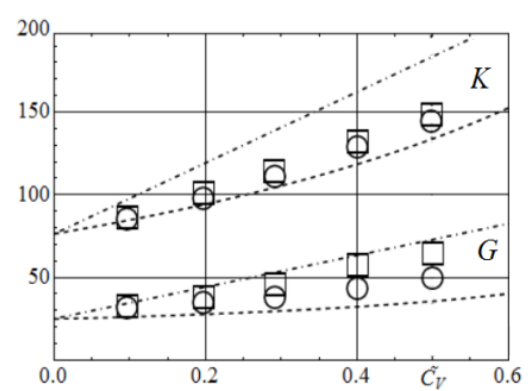

a)

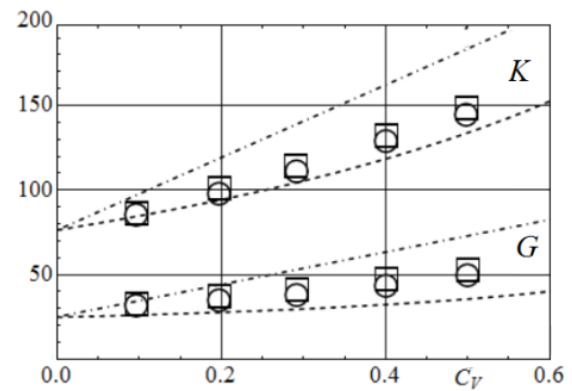

b)

Fig. 2. Comparison of the results of analytical models with a numerical solution, where the periodic cell: a) with the eighth parts of the ball in the corners of the cube;

b) with the ball in the center of the cube 
Fig. 2 compares the results obtained by various methods: numerical and analytical: squares represent the values obtained with the help of kinematic BC; circles with the help of power BC; dashed and dash-dotted lines the lower and upper bounds obtained using the dual formulation of the elasticity problem in an inhomogeneous solid. Fig. 2 shows the estimates of the bulk modulus of elasticity $K$ coincide for the selected periodic cells, and for the module $\mathrm{G}$ the kinematic BC lead to a result that differs significantly from the values obtained by the $\mathrm{BC}$ forces, which can be explained by the following: in the case of a model with eight parts of the ball in the corners of the cube, on the face, where there is a sharp difference in the rigidity at the boundary of the matrix and the inclusion, which leads to ascending in the values of the module $G$.

Fig. 2 also shows that the results of numerical simulation lie between estimates obtained with the help of analytical models.

Conclusion. Mathematical modeling of the elastic characteristics of a composite reinforced with ball nanoclusters from chaotically oriented SCNT was carried out in several ways: numerical (in the ANSYS software package using server processors and TESLA video cards together with the developed software module) and analytical (variational approach). Numerical modeling was carried out with the example of a composite with a reinforcement scheme similar to a cubic crystal lattice. Based on the results of the simulation, it was found that when using different equivalent periodic cell composites for the bulk modulus of elasticity of the composite, the same values were obtained, and for the shear modulus the use of kinematic BC in the case of a periodic cell with eighth parts of the ball in the corners leads to a jump in the values. The results of numerical simulation are compared with the values obtained by the analytical method. It is established that the values obtained by numerical simulation lie between two-sided estimates obtained by means of the dual formulation of the elasticity problem in an inhomogeneous solid. The constructed finite-element model allows to predict the elastic characteristics of composites reinforced with globular inclusions, as well as nanostructured objects of the spherical shape.

\section{References}

1. Biksha D. Ispol'zovaniye kompozitnykh materialov $\mathrm{v}$ oboronnoy promyshlennosti i aerokosmicheskoy industrii / per. s angl. V. Rentyuk // Vestnik elektroniki. 2014. № 1. pp. 24 - 27.

2. Spravochnik po kompozitnym materialam. V dvukh knigakh. Kniga. 1: trans. s angliyskim. A.B. Geller et al., Ed. J. Lubin, B.E. Geller. M.: Mashinostroyeniye, 1988. 448 p.

3. Vasil'yev V.V. Mekhanika konstruktsiy iz kompozitsionnykh materialov. M.: Mashinostroyeniye, 1988. 272 p.

4. Palermo P. Strukturnyye keramicheskiye nanokompozity: obzor svoystv i metody sinteza poroshkov // Nanomaterialy. 2015. V. 5. № 2. pp. 656-696.

5. Casati R., Vedani M. Metallicheskiye matrichnyye kompozity, usilennyye obzorom nanochastits // Metally. 2014. V. 4. pp. 65-83.

6. Blakslee O.L., Proctor D.G., Seldin E.J., Spence G.B., Weng T. Elastichnyye konstanty piroliticheskogo grafita s uplotneniyem i neraskrytym // J. Appl. Phys. 1970. V. 41. № 8. pp. 3373 3382. 
7. Sergeyeva Ye.S. Issledovaniye uprugikh kharakteristik kompozitov s ellipsoidal'nymi vklyucheniyami // Molodezhnyy nauchno-tekhnicheskiy vestnik MGTU im. N.E Baumana. Elektron. zhurn. 2015. №. 5. URL: http://sntbul.bmstu.ru/doc/839933.html (data obrashcheniya: 10.01.17).

8. Zarubin V.S. Prikladnyye zadachi termoprochnosti elementov konstruktsiy $\mathrm{M}$.: Mashinostroyeniye, 1985. $296 \mathrm{p}$.

9. Zarubin V.S., Kuvyrkin G.N. Matematicheskiye modeli mekhaniki i elektrodinamiki sploshnoy sredy. M .: Izd-vo MGTU im. N.E. Baumana, 2008. 512 p.

10. Sergeyeva Ye.S. Issledovaniye uprugikh kharakteristik nanokompozitov // Molodezhnyy nauchno-tekhnicheskiy vestnik MGTU im. N.E Baumana. Elektron. zhurn. 2016. №. 8. Rezhim dostupa: http://sntbul.bmstu.ru/doc/846958.html (the date of the application 30.01.2017).

\section{Authors:}

Zarubin Vladimir Stepanovich, Professor, Doctor of Engineering Sciences, The Bauman Moscow State Technical University ( $2^{\text {nd }}$ Bauman Str., 5, Moscow, Russia)

Sergeeva Elena Sergeevna, «JSC Kompozit» (Joint-Stock Company), (Pionerskaya, 4, Korolev, Moscow Region, Russia); postgraduate student, The Bauman Moscow State Technical University ( $2^{\text {nd }}$ Bauman Str., 5, Moscow, Russia) 
УДК 519.6

\section{Математическое моделирование процессов деформации структурно-чувствительного} нанокомпозита *

\section{В.С. Зарубин ${ }^{* *}$, Е.С. Сергеева ${ }^{* * *}$}

Московский государственный технический университет им. Н.Э. Баумана, Москва, Российская Федерация

ОАО «Композит», Королёв, Российская Федерация

Представлены результаты численного моделирования процессов деформации перспективных структурно-чувствительных материалов - нанокомпозитов, для которых характерно наличие резкого изменения значений механических характеристик на границе раздела между матрицей и включением. Поставленная задача решена в конечно-элементном программном комплексе ANSYS с использованием вычислительных ресурсов серверных процессоров и видеокарт TESLA. Для оценки работоспособности численной модели реализован аналитические метод - двойственная вариационная формулировка задачи упругости. Представленные в данной работе результаты позволяют оценить механические характеристики нанокомпозитов, что необходимо при проектировании конструкции из таких материалов.

Ключевые слова: численное моделирование; структурно-чувствительные материалы; граница раздела; деформация; математическое моделирование

\section{Авторы:}

Зарубин Владимир Степанович, профессор, доктор технических наук, Московский государственный технический университет им. Н. Э. Баумана (105005, Россия, Москва, 2-я Бауманская ул., д. 5)

Сергеева Елена Сергеевна, младший научный сотрудник, ОАО «Композит» (141070, Россия, Московская область, г. Королёв, Пионерская, 4); аспирантка, Московский государственный технический университет им. Н. Э. Баумана (105005, Россия, Москва, 2-я Бауманская ул., д. 5)

\footnotetext{
* Работа выполнена в рамках реализации базовой части государственного задания Минобрнауки РФ (проект 9.7784.2017/БЧ), а также в рамках гранта МК-1069.2018.8 программы Президента РФ государственной поддержки молодых кандидатов наук.

** E-mail: zarubin@bmstu.ru

*** E-mail: sergeeva.e.s@ outlook.com
} 